\title{
VARIATIONS OF RED COLOR COVERAGE OF CULTURED NEON TETRA (Paracheirodon innesi) FOR BREEDING IMPROVEMENT STRATEGIES
}

\author{
Ruby Vidia Kusumah"*\#, Dinar Tri Soelistyowati ${ }^{* * *}$, Alimuddin*), and Melta Rini Fahmi*) \\ *) Research Institute for Ornamental Fish Culture, Ministry of Marine Affairs and Fisheries \\ Jl. Perikanan No. 13, Pancoran Mas, Depok City, 16436, West Java, Indonesia \\ *) Department of Aquaculture, Faculty of Fisheries and Marine Sciences, IPB University \\ Jl. Agatis IPB Dramaga Campus, Bogor, 16680, West Java, Indonesia
}

(Received: September 15, 2020; Final revised: March 8, 2021; Accepted: March 8, 2021)

\begin{abstract}
Red color coverage (RCC) is a commercial trait developed and refined to improve the appearance of many ornamental fish commodities. In neon tetra, the status of variation of RCC is not yet investigated or reported. This study aimed to analyze the RCC variation of cultured neon tetra as a basis for breeding strategies. A total of 900 neon tetras (standard length, SL, of $2.29 \pm 0.16 \mathrm{~cm}$ ) were collected from Bojongsari, Curug, and Pondok Petir fish farms located in Depok Districts, West Java. All fish were relocated and reared in a fish farm specialized in culturing neon tetra for two weeks using nine aquariums with photoperiod set up of 12 hours bright and 12 hours dark. The RCC traits were determined according to the percentages of RCC length (\%RCC), RCC width (\%NCC), and RCC area (\%RCC) and quantified using the digital image method. The result showed that the RCC varied by sex, size, and original location $(P<0.05)$ in a low coefficient of variation $(1.89 \% 11.41 \%$. The RCC values in the male group were higher than that of females based on \%RCC and \%ARCC parameters $(P<0.05)$. Males had the highest \%RCC at size $L X L$, which was correlated with SL $(r 0.25, P<0.1)$, of females at $M$ size. The \%RCC values of the neon tetra population from the Bojongsari farm were higher than those from the other locations. Based on these findings, breeding strategies of the RCC traits should consider sex, size, and population (farm location) variations. Specifically for neon tetra, this strategy should be based on selecting the SL or \%RCC parameter of M for females and LXL for males.
\end{abstract}

\section{KEYWORDS: aquaculture; digital image; Paracheirodon innesi; red color coverage; variation}

\section{INTRODUCTION}

Neon tetra (Paracheirodon innesi) is an endemic fish from South America (Weitzman \& Fink, 1983) and has been the main export commodity of ornamental fish from Indonesia (BRBIH, 2011; Putra, 2014). This characid member is cultured in West Java with its production center located at Bojongsari Subdistrict, Depok City. The total production of neon tetra from the production center was reported to reach 25.3 million fish per year (DKP3, 2018).

The wild type of neon tetra is characterized by (a) a dark brown-black strip on the dorsal area; (b) a greenblue strip on the lateral side; and (c) a red pigment

* Correspondence: Research Institute for Ornamental Fish Culture, Ministry of Marine Affairs and Fisheries JI. Perikanan No. 13, Pancoran Mas, Depok City, 16436, West Java, Indonesia.

E-mail: rubyvkusumah@kkp.go.id; dinarsoegono@gmail.com from the caudal fin to the middle of the body (Weitzman \& Fink, 1983). Other varieties, including albino, xanthic, golden strip, and blue diamond spots on the head, were resulted from aquaculture fish breeding through random mating (Balon, 2004; Live Aquaria, 2019; Seriously Fish, 2019). These varieties contributed to increasing variety and prices (Rodi Fish Farm, 2019). In the ornamental fish business, the development or refining of a fish strain is essential to improve the strain variants' characteristics, price, and quality (Shaddock, 2012; AquariumGlaser, 2020).

Red color coverage (RCC) is a commercial trait that is interesting to consumers and has been developed in many ornamental fish commodities (Colihueque \& Araneda, 2014; Li et al., 2015; De Kock $\&$ Gomelsky, 2016). The RCC trait breeding strategies that have been developed include extending, narrowing, or eliminating the body's red color areas 
(Shaddock, 2012; Pedersen, 2013). Some studies of RCC in fish have been carried out, including quantification techniques, variation analysis, crossbreeding between fish with different percentages of RCC, and analysis of RCC controlling gene (David et al., 2004; Novelo \& Gomelsky, 2009; Du et al., 2018). In neon tetra, scientific information on the variation of RCC is not yet investigated or reported.

Color variations, including RCC, can be influenced by genetic, sex, size, physiological responses, and environmental conditions (David et al., 2004; Parichy et al., 2009; Kelley et al., 2016; Meilisza et al., 2017; Linhares et al., 2018). The RCC variations are essential to reveal the status of color performance of cultured neon tetra based on sex, size, and farm location to improve breeding techniques of the fish species. Based on the farm location, neon tetra populations could have different genetic variations (see Sahoo et al., 2018) influenced by environmental factors, feed management, and the farming system itself. Bojongsari, Curug, and Pondok Petir are villages in the Bojongsari sub-district (Figure 1), where most fish farmers cultivate neon tetra. Preliminary surveys and interviews revealed the farms in these locations show similarities in rearing conditions (Table 1), feed management and farming systems. In these locations, neon tetra is cultivated in one-meter aquariums with a stagnant water system and daily siphoning. Fish were fed twice a day with Artemia, Moina sp., Tubifex (adlibitum), or commercial pellets (at satiation). However, based on trade, farms chosen for this study in each location are not connected (fragmented). Therefore, the population with no interaction with other populations can exhibit different genetic variations/ structures (Beer et al., 2019).

This study aimed to analyze the RCC variation of cultured neon tetra as a basis for breeding strategies. The research was expected to improve the breeding techniques and overall quality of farmed neon tetra, specifically its red color coverage variations.

\section{MATERIALS AND METHODS}

The research was performed between $M$ arch and May 2019 in a fish farm at the Neon Tetra Culture Center, Curug, Bojongsari Subdistrict, Depok City, West Java. In Indonesia, this location is the center of production of neon tetra and supported by multiple culture facilities.

\section{Fish Collection and Maintenance}

A total of 900 neon tetras measuring the $M-X L$ sizes of red border length (RBL) ranging in 1.9-2.7 cm were collected from three fish farms located in
Bojongsari, Curug, and Pondok Petir villages of Bojongsari Subdistricts (Figure 1). The rearing parameters in each fish farm, including temperature, $\mathrm{pH}, \mathrm{TDS}, \mathrm{DO}$, and light intensity (Table 1), were measured in the morning, noon, and afternoon for three days. The measurements were carried out in the sampled aquariums used for the broodstock, larvae, and juvenile. The fish were then separated into nine groups using the combination of fish location and size ( $M, M L, L-X L)$. The fish groups were kept in nine $100 \mathrm{~cm} \times 50 \mathrm{~cm} \times 30 \mathrm{~cm}$ aquariums of $25 \mathrm{~cm}$ water height with 100 fish/aquarium density. Each aquarium has a photoperiod set up of $12 \mathrm{~h}$ light : $12 \mathrm{~h}$ dark and was continuously aerated to maintain dissolved oxygen (D0) level $\geq 3 \mathrm{mg} \mathrm{L}^{-1}$ (SNI 8111: 2015 (BSN, 2015)). The fish rearing media was previously added with approximately $2 \mathrm{~g} \mathrm{~L}^{-1}$ of salt and 12 pieces of dried "ketapang" leaves (Terminalia catappa) folded and bound with rubber bands. Ketapang leaves were used to create culture media resembling neon tetra habitat in black water, lowering the $\mathrm{pH}$, and sources of humic substances (humic acid, fulvic acid, tannin, flavonoid) beneficial to the fish health. Fish were feed twice daily, with Moina sp. (ad-libitum) in the morning and Tubifex (ad-libitum), or commercial pellets (at satiation) in the afternoon. Every two days, the aquariums were siphoned and measured its water quality and ambient parameters, including temperature, pH, DO, total dissolved solid (TDS), and light intensity.

\section{Documentation and Characterization of RCC}

After maintenance of 14 days, fish samples were photographed one by one to document their RCC on a $10 \mathrm{~cm}$-diameter petri dish with a light intensity condition of 310.9-726 lux. Each fish was photographed five times on each body side and then returned to the aquarium. The camera used in the RCC documentation was Canon EOS 450D, positioned 30 $\mathrm{cm}$ from the sample in a perpendicular $\left(90^{\circ}\right)$ direction. The camera setting used focal length: $55 \mathrm{~mm}$, no flash, F-number $F / 5.6$, exposure time: $1 / 60 \mathrm{sec}-$ ond. Digital photos (images) produced were saved in the "JPEG" format with a resolution of $4272 \times 2848$ pixels (12.2 Megapixels). The total number of fish analyzed from each location was 36 fish considering the fish sex composition (1:1) and size (total 108 fish). Male, female, and sizes of fish were randomly collected from nine maintenance aquariums. Sex was determined by morphological dimorphism. The male has a slender and longer body, while the female is rounder and broader on the abdomen. Based on the dorsal viewpoint, the female stomach swells while the male is flat. The neon tetra breeder guided sex 


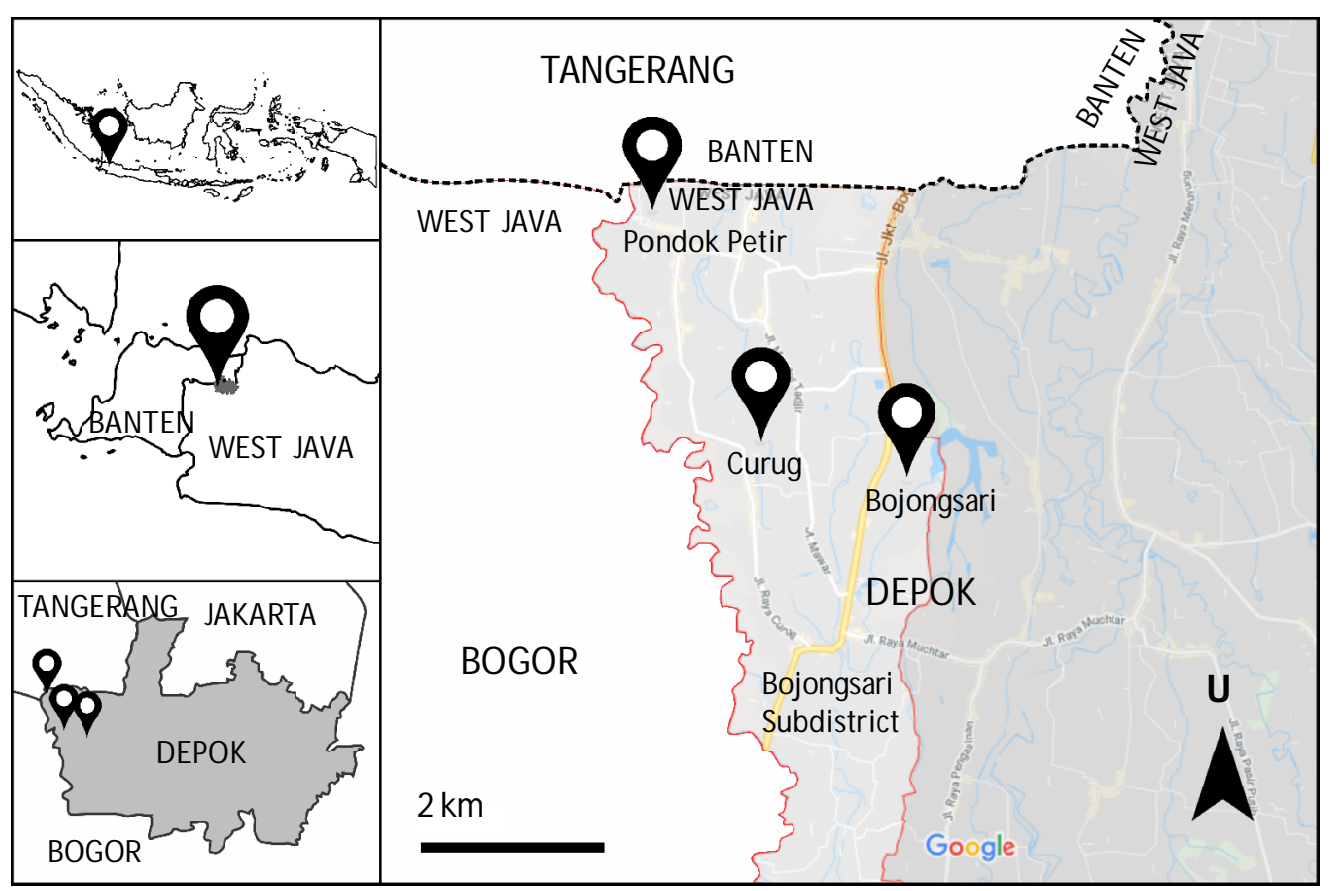

Figure 1. Locations of sampled neon tetra fish farms, Depok, West Java.

Table 1. Variations of water quality and ambient parameters of the rearing aquariums in the sampled fish farms, Depok, West Java

\begin{tabular}{lccccc}
\hline \multicolumn{1}{c}{ Parameters } & Notes & Bojongsari & Curug & Pondok Petir & References* \\
\hline Temperature $\left({ }^{\circ} \mathrm{C}\right)$ & Mean $\pm \mathrm{SD}$ & $26.60 \pm 0.58^{\mathrm{a}}$ & $26.45 \pm 0.72^{\mathrm{a}}$ & $26.31 \pm 0.78^{\mathrm{a}}$ & $25-32.97^{\mathrm{wz}}$ \\
pH & Mean $\pm \mathrm{SD}$ & $5.64 \pm 1.31^{\mathrm{a}}$ & $5.61 \pm 0.93^{\mathrm{a}}$ & $5.83 \pm 0.85^{\mathrm{a}}$ & $4.39-7.34^{\mathrm{xy}}$ \\
DO $\left(\mathrm{mg} \mathrm{L}^{-1}\right)$ & Mean $\pm \mathrm{SD}$ & $5.55 \pm 1.17^{\mathrm{a}}$ & $4.52 \pm 1.45^{\mathrm{b}}$ & $4.40 \pm 1.02^{\mathrm{b}}$ & $0.32-8.29^{\mathrm{z}}$ \\
TDS $\left(\mathrm{mg} \mathrm{L}^{-1}\right)$ & Mean $\pm \mathrm{SD}$ & $1.44 \pm 0.92^{\mathrm{a}}$ & $1.17 \pm 0.78^{\mathrm{a}}$ & $1.22 \pm 0.83^{\mathrm{a}}$ & - \\
Light intensity (lux) & & $6-5,560$ & $8.3-467$ & $11-1,826$ & - \\
\hline
\end{tabular}

Note: Mean \pm SD shows mean and standard deviation measured in broodstock, larvae, and juvenile rearing aquariums in the morning, noon, and afterno on for three days. Values with different superscript letters in the same row show significant differences (Fisher's LSD test, $\mathrm{P}<0.05)$. ${ }^{*}$ Chapman et al. (1998); ${ }^{\mathrm{X}}$ Horbe et al. (2009); ' 'Rios-Villamizar et al. (2014); ${ }^{2}$ Rodrigues-Filho et al. (2015)

determination to ensure accuracy. The size criteria were determined based on the red border length, measured from the mouth to the red border on the caudal fin. The measurement of red border length $(\mathrm{RBL})$, standard length (SL), body area (BA), and RCC traits, including LRCC (RCC length), WRCC (RCC width), ARCC (RCC area) (Figure 2), were performed using Adobe Photoshop CS5 Extended software version $12.0 \times 64$. The LRCC and WRCC parameters were divided by SL (\%RCC and \%ARCC), while ARCC was the percentage of BA (\%ARCC) (Kusumah et al., 2016).
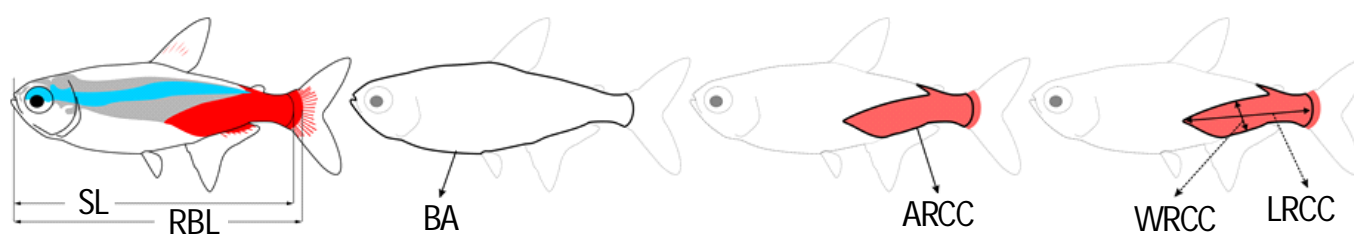

Figure 2. Size measurement and red color coverage (RCC) quantification. RBL: red border length, SL: standard length, BA: body area, LRCC: RCC length, WRCC: RCC width, ARCC: RCC area. 


\section{Data Analysis}

The data obtained were classified by sex, size, and location. The size of fish was categorized based on the standard neon tetra market size: $M(1.9-2.1$ $\mathrm{cm} \mathrm{RBL}), \mathrm{ML}$ (2.2-2.3 cm RBL), L (2.4-2.5 cm RBL), LXL (2.5-2.6 cm RBL), XL ( $\geq 2.7 \mathrm{~cm} \mathrm{RBL}$ ) converted to standard length (SL). RBL and SL correlation are depicted by a linear regression model in the total samples (A: pooling, 108 fish). SL comparison tests based on sex (B: 54 samples for each sex), size (C: 4-43 samples for each size), and location (D: 36 samples for each location) were analyzed using ANOVA followed by the LSD Fisher test. Population estimation of the SL parameter was calculated using the formula:

$$
\text { Mean } \pm 1.96 \times\left(\frac{\mathrm{SD}}{\sqrt{\mathrm{n}}}\right)
$$

Information: $n=$ number of samples

Based on the RCC parameters (\%RCC, \%NRCC, $\% A R C C$ ), sex criterion was firstly used to analyze RCC variations. There were 54 samples for each sex (B) to compare RCC variations on fish male and female. If the RCC variation of sex criteria revealed a significant difference, the comparison test was repeated with size and location criteria in each sex. Total samples of $M: M L: L: L X L: X L$ sizes respectively were 3:13:21:14:3 fish for male and 3:23:22:5:1 fish for female (E). Based on location, total samples of Bojongsari : Curug : Pondok Petir farms respectively were 18:18:18 fish for each sex (F).

Normal distributions of RCC variations were analyzed using the Kolmogorov-Smirnov test (KS). The homogeneity test used the Levene test (LV). The coefficient of variations (CV) was analyzed descriptively. The RCC comparison based on sex (B), size $(E)$, and location (F) were analyzed using ANOVA followed by the LSD Fisher's test, correlation test, and regression of RCC parameters with SL (B) and within RCC parameters (\%RCC, \%NRCC, \%ARCC) (B). The KruskalWallis test were used to analyse RCC parameters that were not normally distributed and/or homogenous. The similarity of Total RCC (\%RCC + \%NRCC + $\% A R C C$ ) between locations (D) and between SL, BA, LRCC, WRCC, and ARCC values (A) were analyzed using cluster analysis. Data are presented in tables and graphs. All data analyses were carried out using Minitab 16.2.4.0 and Microsoft Excel software.

\section{RESULTS AND DISCUSSION}

\section{Standard Length Variations of Neon Tetra}

The standard length (SL) of neon tetra varied with the coefficient of variation (CV) range from $1.71 \%$
7.32\% (Table 2). The SLs of male fish groups were higher than that of the females $(P<0.05)$. Meanwhile, the fish from Bojongsari farm had longer body length than those of the other locations $(P<0.05)$. Each size group showed significant differences $(P<0.05)$ with the lowest CV for size $M$ and the highest CV for a size $\mathrm{XL}$. The estimated range of variation in the $\mathrm{SL}$ at the population level was higher and tighter than the sample data range. In breeding programs, the low range and variation of the population were positively correlated with selection intensity and selection response.

The standard length of samples in this study ranged between 1.93-2.76 cm (2.01-2.84 cm RBL) or $\mathrm{M}-\mathrm{XL}$ size (Table 2), which showed that RCC characters have developed (Supplement 1). According to Chapman et al. (1998), the color has appeared in neon tetra larvae like in the adult fish on 28-32 days after hatching, categorized as $\mathrm{S}$ size ( $\pm 1 \mathrm{~cm} \mathrm{RBL}$ ). The S-sized fish needs about 45 days more to reach $M$ size (1.9-2.1 $\mathrm{cm} R B L)$. Red border length (RBL) is the standard parameter for determining the neon tetra's market size used in the Bojongsari Sub-district. In this study, RBL significantly correlated to standard length (SL) $(r=$ $0.99, \mathrm{P}<0.001$ ) with the regression model is: $\mathrm{SL}=$ $-0.0120+0.972 \mathrm{RBL}\left(\mathrm{R}^{2}=0.97, \mathrm{P}<0.001\right)$.

\section{Red Color Coverage Variation of Neon Tetra}

The red color coverage (RCC) character values, including \%RCC, \%NRCC, and \%ARCC indicated normal and homogeneous distribution patterns $(P>0.05)$, except the \%RCC in the male fish population from the Bojongsari farm and the \%ARCC from Curug farm $(P<0.01)$. Several studies reported that color characters could be categorized as qualitative traits influenced by single or multiple genes (David et al., 2004; Gorshkov, 2014) or quantitative traits that can be measured, normally distributed, controlled by many genes influenced by environmental conditions (Gomelsky, 2011). The results of this research have confirmed that the RCC character in neon tetra is categorized as a quantitative trait (Kusumah et al., 2016; Rankin et al., 2016; Meilisza et al., 2017) and valid for parametric analysis.

The RCC performances of the neon tetra samples were significantly different $(P<0.05)$ based on sex, size, and farm location, with the coefficient of variations (CV) ranging from $1.89 \%$ to $11.41 \%$ (Table 3 ). This variation of RCC is lower than the variation in the brown coverage in Cynoglossus semilaevis by $63.78 \%$ (Liu et al., 2016), and other colors such as black $(23 \% 75 \%$, blue $(16.7 \% 75 \%)$, iridescent $(25 \%$ $53.8 \%$, orange $(25 \% 66.7 \%)$ of Poecilia reticulata (Martínez et al., 2016). 
Table 2. Variations of the standard length of neon tetra population based on sex, size, and farming location

\begin{tabular}{|c|c|c|c|c|c|c|}
\hline \multirow{2}{*}{ Criteria } & \multirow{2}{*}{ Groups } & \multicolumn{4}{|c|}{ Samples } & \multirow{2}{*}{$\frac{\text { Population estimatior }}{\text { Range }(\mathrm{cm})}$} \\
\hline & & $\mathbf{N}$ & Mean \pm SD $(\mathrm{cm})$ & CV $(\%)$ & Range $(\mathrm{cm})$ & \\
\hline \multirow{2}{*}{ Sex } & Male & 54 & $2.33 \pm 0.17^{\mathrm{a}}$ & 7.32 & $1.93-2.74$ & $2.28-2.38$ \\
\hline & Female & 54 & $2.25 \pm 0.14^{b}$ & 6.06 & $2.00-2.76$ & $2.21-2.29$ \\
\hline \multirow{5}{*}{ Size } & $M$ & 6 & $1.99 \pm 0.03^{\mathrm{e}}$ & 1.71 & $1.93-2.02$ & $1.97-2.01$ \\
\hline & $M L$ & 36 & $2.14 \pm 0.05^{d}$ & 2.36 & $2.07-2.29$ & $2.12-2.16$ \\
\hline & $\mathrm{L}$ & 43 & $2.32 \pm 0.06^{c}$ & 2.57 & $2.21-2.41$ & $2.30-2.34$ \\
\hline & LXL & 19 & $2.46 \pm 0.05^{b}$ & 1.84 & $2.35-2.54$ & $2.44-2.48$ \\
\hline & $X L$ & 4 & $2.69 \pm 0.07^{\mathrm{a}}$ & 6.91 & $2.62-2.76$ & $2.62-2.76$ \\
\hline \multirow{3}{*}{ Location } & Bojongsari & 36 & $2.38 \pm 0.17^{\mathrm{a}}$ & 7.10 & $2.02-2.76$ & $2.32-2.44$ \\
\hline & Curug & 36 & $2.27 \pm 0.12^{b}$ & 5.46 & $2.07-2.51$ & $2.23-2.31$ \\
\hline & Pondok Petir & 36 & $2.22 \pm 0.13^{b}$ & 6.07 & $1.93-2.45$ & $2.18-2.26$ \\
\hline
\end{tabular}

Note: Values with different superscript letters in the same criteria and columns indicate a significant difference (Fisher's LSD test, $\mathrm{P}<0.05$ ). N: Number of samples, M: $1.9-2.1 \mathrm{~cm} \mathrm{RBL}, \mathrm{ML}: 2.2-2.3 \mathrm{~cm}$ RBL, L: 2.4-2.5 cm RBL, LXL: 2.6-2.7 cm RBL, XL: > $2.7 \mathrm{~cm} \mathrm{RBL} \mathrm{(RBL:} \mathrm{red} \mathrm{border} \mathrm{length,} \mathrm{SD:} \mathrm{standard}$ deviation, CV: coefficient of variation).

The variation value of a character is the basis for developing strains through breeding (Shaddock, 2012; Kottler et al., 2013; Ponzoni et al., 2013; Moses et al., 2020), including red color coverage. Genetically, the red color is controlled by multiple genes, the same genes controlling the synthesis of pteridine and melanin, metabolism of tyrosine, and genes related to cell responses to stress (Li et al., 2015; Zhang et al., 2017). In neon tetra, the performance of red color is influenced by light conditions, which could increase or fade fish's color intensity (Hayashi et al., 1999; Linhares et al., 2018). Based on sex criteria, the RCC variation in male fish is generally lower than the females. According to fish size, the LXL group has a higher variation than the other sizes. Based on farm location, the fish population from Bojongsari was more varied than others (Table 3 ).

In certain fish species, sex is a morphological criterion to distinguish between male and female (sexual dimorphism) in aquaculture broodstock selection. In general, the character performance of males is more attractive than females (Camelier et al., 2018; Kottler $\&$ Schartl, 2018). This research showed that $\%$ RCC and \%ARCC values in males were higher than that of females $(P<0.05)$ (Table 3$)$. However, farmers usually differentiate the sex of neon tetra based on the shape, size, and color of the abdomen. For example, the abdomen is yellowish for females or blackish for males, or the body shape is slender and elongated for males but rounded and widened for females. Based on the size and location criteria, the sexual charac- teristics of male RCC were more varied and significant $(P<0.05)$ but tended to be stable in females $(P>0.05)$ (Table 3). This information can be used as a basis for consideration when selecting male neon tetra with specific RCC characters.

The male fishes sized $L X L$ have the highest $\% R C C$ and \%ARCC $(\mathrm{P}<0.05)$ compared to the other sizes with a difference of $1.5 \% 4.6 \% \mathrm{SL}$ and $0.08 \% 3.38 \% \mathrm{BA}$, respectively (Table 3 ). The $\%$ RCC values in the male fish group showed an increasing trend followed by an increase in size from $M$ to $L X L$, whereas female fish indicated a declining trend. These results confirmed that the RCC trait has optimal limits, which differ by sex. The optimal limit of RCC in male fish is at LXL size. In contrast, the female limit is at M size. The size is an indicator of the morphological (ontogeny) development of fish species (Parichy et al., 2009). In immature fish, its morphological character has not developed yet, including color traits (Parichy et al., 2009; Baras et al., 2012; Marinho, 2017; Salis et al., 2018).

The male fish from Bojongsari farm showed the highest \% RCC variation of between $0.7 \% 1.6 \% \mathrm{SL}$ compared to the fish populations from other locations (Table 3). Each farming location may have specific characteristics of environmental factors, including water quality, food availability, management, systems, aquaculture technology, and the possibility of gene flow between fish farm populations. In some aquaculture species, several parameters affect morphological variations, including body-color character. This 
Table 3. Variations of red color coverage (RCC) of neon tetra based on sex, size, and farming location in Depok, West Java, Indonesia

\begin{tabular}{|c|c|c|c|c|c|c|c|c|}
\hline \multirow{2}{*}{ Criteria } & \multirow{2}{*}{\multicolumn{2}{|c|}{ RCC Param eters }} & \multicolumn{3}{|c|}{ Male } & \multicolumn{3}{|c|}{ Female } \\
\hline & & & $\mathbf{N}$ & Mean \pm SD & CV $\%$ \% & $\mathbf{N}$ & Mean \pm SD & CV $(\%)$ \\
\hline \multirow[t]{3}{*}{ Sex } & $\%$ RCC & & 54 & $48.74 \pm 2.25^{a}$ & 4.62 & 54 & $45.81 \pm 2.08^{b}$ & 4.53 \\
\hline & oANRCC* & & 54 & $13.10 \pm 0.83^{\mathrm{a}}$ & 6.30 & 54 & $13.12 \pm 1.13^{\mathrm{a}}$ & 8.59 \\
\hline & $\% A R C C$ & & 54 & $22.39 \pm 1.31^{\mathrm{a}}$ & 5.83 & 54 & $20.22 \pm 1.65^{b}$ & 8.15 \\
\hline \multirow[t]{15}{*}{ Size } & $\% \mathrm{dRCC}$ & M & 3 & $47.67 \pm 2.16^{\text {abcde }}$ & 4.52 & 3 & $46.83 \pm 1.74^{\text {bcde }}$ & 3.72 \\
\hline & & $M L$ & 13 & $48.10 \pm 2.17^{b}$ & 4.51 & 23 & $45.97 \pm 2.02^{\mathrm{de}}$ & 4.40 \\
\hline & & $\mathrm{L}$ & 21 & $48.49 \pm 1.97^{b}$ & 4.05 & 22 & $45.45 \pm 1.84^{\mathrm{e}}$ & 4.04 \\
\hline & & LXL & 14 & $50.00 \pm 2.66^{a}$ & 5.31 & 5 & $45.66 \pm 3.57^{\text {cde }}$ & 7.82 \\
\hline & & $X \mathrm{~L}$ & 3 & $48.40 \pm 0.91^{\mathrm{abcd}}$ & 1.89 & 1 & 47.77 & 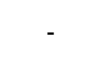 \\
\hline & \%NRCC & $M$ & 3 & $13.53 \pm 0.73^{\mathrm{a}}$ & 4.68 & 3 & $13.48 \pm 0.58^{\mathrm{a}}$ & 4.32 \\
\hline & & $M L$ & 13 & $13.06 \pm 0.73^{a}$ & 7.51 & 23 & $13.20 \pm 1.05^{\mathrm{a}}$ & 7.98 \\
\hline & & $\mathrm{L}$ & 21 & $13.00 \pm 1.03^{\mathrm{a}}$ & 6.34 & 22 & $13.10 \pm 1.28^{\mathrm{a}}$ & 9.77 \\
\hline & & LXL & 14 & $13.10 \pm 0.73^{a}$ & 5.38 & 5 & $12.89 \pm 1.16^{\mathrm{a}}$ & 9.01 \\
\hline & & $X \mathrm{~L}$ & 3 & $13.50 \pm 0.73^{a}$ & 8.19 & 1 & 11.83 & - \\
\hline & $\% A R C C$ & $M$ & 3 & $21.48 \pm 1.17^{\mathrm{ab}}$ & 5.42 & 3 & $20.93 \pm 0.80^{\mathrm{ab}}$ & 3.81 \\
\hline & & $M L$ & 13 & $22.47 \pm 1.25^{\mathrm{a}}$ & 5.56 & 23 & $20.24 \pm 1.54^{b}$ & 7.60 \\
\hline & & $\mathrm{L}$ & 21 & $22.43 \pm 1.31^{a}$ & 5.84 & 22 & $20.21 \pm 1.78^{b}$ & 8.82 \\
\hline & & LXL & 14 & $22.55 \pm 1.44^{\mathrm{a}}$ & 6.37 & 5 & $19.91 \pm 2.27^{b}$ & 11.41 \\
\hline & & $X \mathrm{~L}$ & 3 & $22.06 \pm 1.50^{\mathrm{ab}}$ & 6.78 & 1 & 19.17 & - \\
\hline \multirow[t]{9}{*}{ Location } & $\%$ RCC* & Bjs & 18 & $49.48 \pm 2.44^{a}$ & 4.93 & 18 & $45.86 \pm 2.64^{c}$ & 5.76 \\
\hline & & $\mathrm{Crg}$ & 18 & $48.82 \pm 2.26^{\mathrm{ab}}$ & 4.63 & 18 & $45.85 \pm 1.92^{c}$ & 4.20 \\
\hline & & Ptr & 18 & $47.92 \pm 1.86^{b}$ & 3.88 & 18 & $45.72 \pm 1.66^{c}$ & 3.62 \\
\hline & oANRCC* & Bjs & 18 & $13.14 \pm 0.73^{\mathrm{a}}$ & 5.54 & 18 & $12.93 \pm 0.91^{\mathrm{a}}$ & 7.06 \\
\hline & & $\mathrm{Crg}$ & 18 & $13.11 \pm 0.73^{\mathrm{a}}$ & 5.54 & 18 & $12.99 \pm 1.34^{\mathrm{a}}$ & 10.3 \\
\hline & & Ptr & 18 & $13.04 \pm 1.03^{\mathrm{a}}$ & 7.90 & 18 & $13.45 \pm 1.08^{a}$ & 8.03 \\
\hline & $\% A R C C$ & Bjs & 18 & $22.49 \pm 1.41^{\mathrm{ab}}$ & 6.27 & 18 & $20.33 \pm 1.80^{c}$ & 8.85 \\
\hline & & $\mathrm{Crg}$ & 18 & $22.87 \pm 1.16^{\mathrm{a}}$ & 5.06 & 18 & $20.53 \pm 1.71^{c}$ & 8.31 \\
\hline & & Ptr & 18 & $21.83 \pm 1.18^{b}$ & 5.43 & 18 & $19.79 \pm 1.42^{c}$ & 7.15 \\
\hline
\end{tabular}

Note: Values with different superscript letters for each criterion and RCC parameters indicate significant differences (Fisher's LSD test $P<0.05)$. Asterisk $(*)$ shows a significant difference based on the Kruskal-Wallis test $(P<0.05)$. N: number of samples, SD: standard deviation, CV: coefficient of variation, \%RCC: percentage of RCC length to SL, \%NRCC: percentage width of RCC to SL, \%ARCC: percentage of RCC area to BA, RCC: red color coverage, SL: standard length, BA: body area, Bjs: Bojongsari, Crg: Curug, Ptr: Pondok Petir fish farm. M: 1.9-2.1 cm RBL, ML: 2.2-2.3 cm RBL, L: 2.4-2.5 cm RBL, LXL: $2.6-2.7 \mathrm{~cm}$ RBL, XL: > $2.7 \mathrm{~cm}$ RBL, RBL: red border length

research confirms that the fish population from Bojongsari farm has the highest RCC, which can be considered the basic population in improving the strain and breeding techniques of neon tetra.

\section{Correlation and Regression Analysis Between RCC Parameters in Neon Tetra}

The Pearson correlation analysis and simple linear regression between RCC parameters (Table 4) showed that $\mathrm{ANRCC}$ in female fish was negatively correlated with standard length $(P<0.05)$, and \%ARCC was correlated with \%RCC $(P<0.001)$. These results indicate that the \%RCC parameter could be used as a selection indicator in male fish to obtain the expected \%ARCC, whereas, in female fish, the \%NRCC is used.

\section{Clusters Analysis of RCC Variations in Neon Tetra}

Cluster analysis based on a combination of three RCC parameters (\%RCC, \%NRCC, \%ARCC) showed that neon tetra from different locations showed a high similarity (> 99.5\% (Figure 3). The RCC variations of the fish populations from Curug and Pondok Petir showed a higher resemblance to Bojongsari. The low 
Table 4. Correlation and linear regression of RCC parameters with standard length and intra RCC parameters of neon tetra

\begin{tabular}{|c|c|c|c|c|c|c|c|}
\hline \multirow{2}{*}{ Parameters } & \multirow{2}{*}{ Sex } & \multicolumn{2}{|c|}{ Correlation } & \multicolumn{4}{|c|}{ Regression } \\
\hline & & $\mathbf{r}$ & $\mathbf{p}$ & $\beta_{0}$ & $\beta_{1}$ & $\mathbf{R}^{2}$ & $\mathbf{p}$ \\
\hline \multirow{2}{*}{$\%$ RCC-SL } & Male & 0.25 & 0.06 & 41.00 & 3.35 & $6.40 \%$ & 0.06 \\
\hline & Female & -0.21 & 0.14 & 52.90 & -3.13 & $4.30 \%$ & 0.14 \\
\hline \multirow{2}{*}{ \%ANRCC-SL } & Male & -0.05 & 0.74 & 13.60 & -0.23 & $0.20 \%$ & 0.74 \\
\hline & Female & -0.29 & $*$ & 18.50 & -2.39 & $8.40 \%$ & $*$ \\
\hline \multirow{2}{*}{ \%ARCC-SL } & Male & 0.04 & 0.80 & 21.70 & 0.28 & $0.10 \%$ & 0.80 \\
\hline & Female & -0.26 & 0.06 & 27.20 & -3.08 & $6.50 \%$ & 0.06 \\
\hline \multirow{2}{*}{$\%$ RCC- $\%$ ANRCC } & Male & 0.01 & 0.94 & 48.40 & 0.03 & $0.00 \%$ & 0.94 \\
\hline & Female & 0.06 & 0.69 & 44.50 & 0.10 & $0.30 \%$ & 0.70 \\
\hline \multirow{2}{*}{$\% A R C C-\%$ LRCC } & Male & 0.51 & 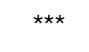 & 7.87 & 0.30 & $26.50 \%$ & $* * *$ \\
\hline & Female & 0.57 & *** & -0.35 & 0.45 & $32.00 \%$ & 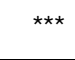 \\
\hline \multirow{2}{*}{ \%ARCC-\%WVRCC } & Male & 0.27 & $*$ & 16.80 & 0.43 & $7.40 \%$ & $*$ \\
\hline & Female & 0.32 & $*$ & 14.00 & 0.47 & $10.50 \%$ & $*$ \\
\hline
\end{tabular}

Note: The asterisks $(*)$ and $(* * *)$ showed significance at $\mathrm{P}<0.05$ and $\mathrm{P}<0.001 . \% \mathrm{RCC}$ : percentage of RCC length to $\mathrm{SL}$, \%ANRCC: percentage width of RCC to SL, \%ARCC: percentage of RCC area to BA, RCC: red color coverage, SL: standard length, $B A$ : body area, $r$ : correlation coefficient, $R^{2}$ : coefficient of determination, $p$ : significance value

RCC variation (Table 3) explains the high similarity of RCC character in neon tetra between locations (Figure 3). This similarity also indicates that gene flow in the three populations still occurs due to high trade intensity and broodstock demands between farmers of these areas. Since 2014, the neon tetra trade from Pondok Petir was disconnected from Curug farm. Meanwhile, since 1994, Bojongsari farm did not supply the fish to Curug farm. However, not all farms in Bojongsari Sub-district have disconnected their trade like the farms chosen for this study. Many farms are still connected due to their proximity (around 2-3 $\mathrm{km}$ ) and supply exchange of neon tetra.

Bojongsari, Curug, and Pondok Petir are three villages that are bordering each other. Based on the survey, most of the water quality and ambient parameters at each location were not significantly different ( $P>0.05$ ), except DO (Table 1). The fish samples were adapted for two weeks at the same place in Curug Fish Farm. The measured ambient and water

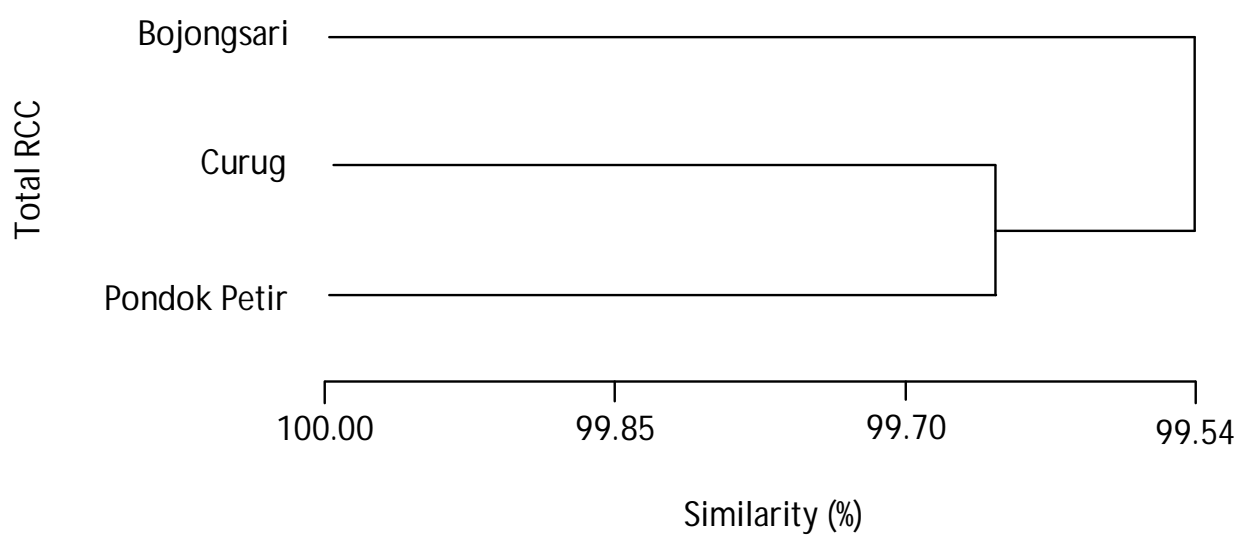

Figure 3. The similarity of total red color coverage (RCC) of neon tetra inter locations. Total RCC $=\% \mathrm{LRCC}+\% \mathrm{AVRCC}+\% \mathrm{ARCC}, \% \mathrm{RCC}$ : percentage of RCC length to SL, \%ANRCC: percentage of RCC width to SL, \%ARCC: percentage of RCC area to BA, RCC: red color coverage, SL: standard length, BA: body area. 
quality parameters of the rearing media were temperature, $\mathrm{pH}, \mathrm{DO}, \mathrm{TDS}$, and light intensity ranged between $27^{\circ} \mathrm{C}-29^{\circ} \mathrm{C}, 3.5-5.7,4.2-5.1 \mathrm{mg} \mathrm{L}^{-1}, 327-979$ $\mathrm{mg} \mathrm{L}^{-1}$, and 70-245.6 lux, respectively. These measurements were conducted before RCC variation documentation (Table 3) to ensure that the source of variation was not from environmental factors but genetic. The low variation of RCC is also possibly affected by the occurrence of inbreeding of neon tetra, so the RCC characteristic tends to be stable from the past until the present. Further, it is necessary to compare the RCC variation of neon tetra from wild and cultured populations.

The relationship analysis between parameters affected RCC variations (\%RCC, \% $\%$ RCC, \%ARCC) in neon tetra showed that standard length (SL) is closely related to body area with $97 \%$ similarity. In comparison, the RCC length (LRCC) is related to RCC area (ARCC) with $94 \%$ of similarity and RCC width (WRCC) shows a close relationship with other parameters at $81 \%$ similarity level (Figure 4).

\section{CONCLUSIONS}

Red color coverage (RCC) variations of neon tetra are influenced by sex, size, and population (farm location). The values of \%RCC and \%ARCC in males are high than in females. The variation of female $\%$ ANRCC is negatively correlated to standard length. The optimal RCC values in males and females are at $L X L$ and $M$ sizes, respectively. The standard lengths and RCC variations of neon tetra populations from Pondok Petir and Curug have a higher similarity to each other than to the fish population from Bojongsari. Breeding strategies of the RCC trait should consider the level variations of sex, size, and population (farm locations). In neon tetra, breeding strategies of the RCC trait should be based on the selection of the standard length or \%RCC parameter of M size for females and $\mathrm{LXL}$ size for males.

\section{ACKNOWLEGMENTS}

The authors thank The Research Institute for Ornamental Fish Culture, Depok, for partially funded the research. The National Outstanding Farmers and Fishermen Association (KTNA) chapter Bojongsari Subdistrict, Community Empowerment Organization (LPM) chapter Curug Village, Rodi Fish Farm, Ape Fish Farm, and Joy Fish Farm are thanked for providing access to farm facilities and fish samples. The authors gratefully acknowledge the following individuals who provided assistance during the research period: Riyon Iki, Robi Darwis, Safendi, Irwan Setiawan, and all of the genetic group members. The authors thank Abdan Julian Kusumah, Isa Budi, and Tarsiwan for their help in data analysis. Sincere thanks to Mrs. Indriyani Kusumah, who significantly contributed to improving the readability of this paper.

\section{REFERENCES}

AquariumGlaser. (2020). Fish archives - Aquarium Glaser $\mathrm{GmbH}$. Retrieved June 11, 2020, from https://www.aquariumglaser.de/en/category/fisharchives/.

Badan Standardisasi Nasional (National Standardization Agency of Indonesia) [BSN]. (2015). Production of neon tetra, Paracheirodon innesi Myers 1936 (SNI 8111:2015). Serpong, Indonesia: BSN.

Balai Riset Budidaya Ikan Hias (Research Institute for Ornamental Fish Culture) [BRBIH]. (2011). Ornamental fish breeding network 2011 report. Depok, Indonesia: Ministry of Maritime Affairs and Fisheries.

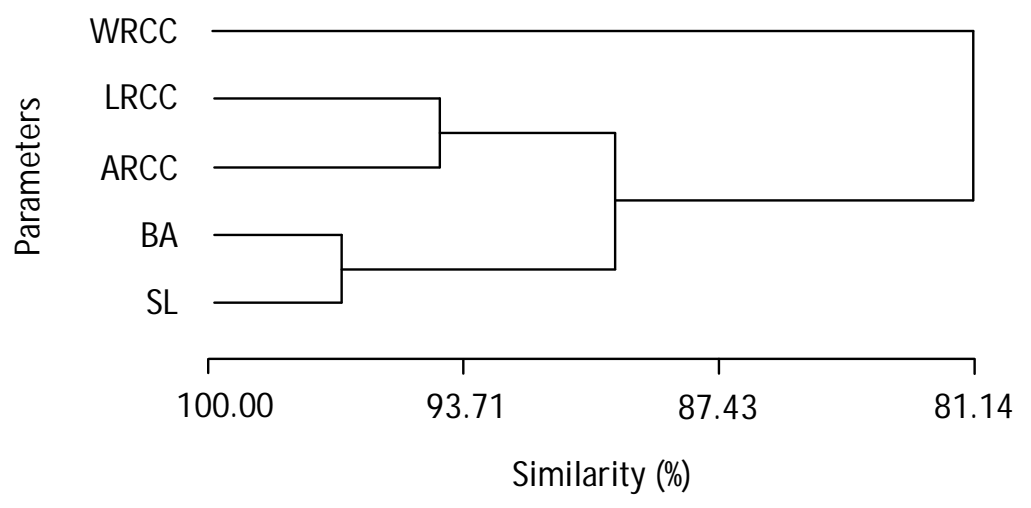

Figure 4. The similarity of the source of variations inter parameters affected by the red color coverage (RCC) of neon tetra. WRCC (RCC width), LRCC (RCC length), ARCC (RCC area), BA: body area, SL: standard length. 
Balon, E.K. (2004). About the oldest domesticates among fishes. J. Fish Biol., 65(Supplement A), 1-27.

Baras, E., Slembrouck, J., Priyadi, A., Satyani, D., Pouyaud, L., \& Legendre, M. (2012). Biology and culture of the clown loach Chromobotia macracanthus Cypriniformes, Cobitidae: 3-ontogeny, ecological and aquacultural implications. Aquat. Living Resour., 25, 119-130.

Beer, S.D., Cornett, S., Austerman, P., Trometer, B., Hoffman, T., \& Bartron, M.L. (2019). Genetic diversity, admixture, and hatchery influence in Brook Trout (Salvelinus fontinalis) throughout western New York State. Ecology and Evolution, 9, 74557479.

Camelier, P., Dagosta, F., \& Marinho M.M.F. (2018). New remarkable sexually dimorphic miniature species of Hyphessobrycon Characiformes/ : Characidae from the upper Rio Tapajós basin. J. Fish. Biol. doi:10.1111/jfb.13579.

Chapman, F.A., Colle, D.E., Rottmann, R.W., \& Shireman, J.V. (1998). Controlled spawning of the neon tetra. Progress. Fish Cult., 60, 32-37.

Colihueque, N. \& Araneda, C. (2014). Appearance traits in fish farming: Progress from classical genetics to genomics, providing insight into current and potential genetic improvement. Front. Genet., 5(251), 1-8.

David, L., Rothbard, S., \& Rubinstein, I. (2004). Aspects of red and black color inheritance in the Japanese ornamental Koi carp Cyprinus carpio L. Aquaculture, 233, 129-147.

De Kock, S. \& Gomelsky, B. (2015). Japanese ornamental koi carp: Origin, variation and genetics. In Pietsch, C. \& Hirsch, P. (Eds). Boca Raton, US: CRC Press, Biology and Ecology of Carp, p. 27-53.

Dinas Ketahanan Pangan Pertanian dan Perikanan (The Department of Food Security, Agriculture, and Fisheries) [DKP3]. (2018). Statistical reports on the production of ornamental fish cultivation and its value based on fish type (ornamental fish). Depok, Indonesia: Depok City Government.

Du, J., Chen, X., Wang, J., Chen, H., Yue, W., \& Lu, G. (2018). Comparative skin transcriptome of two Oujiang color common carp Cyprinus carpio var. color varieties. Fish Physiol. Biochem., 45, 177185.

Liu, F., Yang, Y., Li, Y., Guo, H., Dai, H., Gao, J., ... \& Chen, S. (2016). Phenotypic and genetic parameter estimation of juvenile growth and bottom color traits in half-smooth tongue sole,
Cynoglossus semilaevis. Acta Oceanol Sin., 35(10), 83-87.

Gomelsky, B. (2011). Fish genetics: Theory and practice. Saarbrucken, German: VDM Publishing.

Gorshkov, B.S. (2014). Inheritance of a darkened caudal peduncle and yellow body coloration in the gilthead seabream Sparus aurata L. J. Appl. Ichthyol., 30, 441-447.

Hayashi, H., Sugimoto, M., Oshima, N., \& Fuji, R. (1999). Circadian motile activity of erythrophores in the red abdominal skin of tetra fishes and its possible significance in chromatic adaptation. Pigment Cell Res., 6, 29-36.

Horbe, A.M.C., Ana, G., \& Santos, S. (2009). Chemical composition of black-watered rivers in the Western Amazon region (Brazil). J. Braz. Chem. Soc., 20(6), 1119-1126.

Kelley, J.L., Rodgers, G.M., Morrell, L.J., \& Kelley, J.L. (2016). Conflict between background matching and social signalling in a colour-changing freshwater fish. R. Soc. Open Sci., 3, 160040.

Kottler, V.A., Fadeev, A., Weigel, D., \& Dreyer, C. (2013). Pigment pattern formation in the guppy, Poecilia reticulata, involves the Kita and Csf1ra receptor tyrosine kinases. Genetics, 194(July), 631-646.

Kottler, V.A. \& Schartl, M. (2018). The colorful sex chromosomes of teleost fish. Genes, 9(233), 1-16.

Kusumah, R.V., Prasetio, A.B., Kusrini, E., Hayuningtyas, E.P., \& Cindelaras, S. (2016). Color and genotype performance of black percula strain clownfish Amphiprion sp. broodstock (F0). J. Ris. Akuakultur, 11(1), 47-58.

Li, X.M., Song, Y.N., Xiao, G.B., Zhu, B.H., Xu, G.C., Sun, M.Y., ... \& Li, J.T. (2015). Gene expression variations of red-white skin coloration in common carp Cyprinus carpio. Int. J. Mol. Sci., 16(9), 21310-21329.

Linhares, R.M., Pinagé, C.M., \& Duncan, W.P. (2018). Excessive luminosity fades the skin color of cardinal tetra. Bol. Inst. Pesca, 44, 319.

Live Aquaria. (2019). Gold neon tetra: Tropical fish for freshwater aquariums. Retrieved June 12, 2019, from https://m.liveaquaria.com/product/898/ ? catid $=898$.

Marinho, M.M.F. (2017). Comparative development in Moenkhausia pittieri and Paracheirodon innesi Ostariophysi/ : Characiformes with comments on heterochrony and miniaturization in the Characidae. J. Fish. Biol., (July), p. 1-2. 
Martínez, C., Chavarría, C., Sharpe, D.M.T., \& De León, L.F. (2016). Low predictability of color polymorphism in introduced guppy Poecilia reticulata populations in Panama. PLoS ONE, 11(2), e0148040.

Meilisza, N., Jusadi, D., Zairin, M., Artika, I. M., Utomo, N.B.P., Kadarini, T., \& Suprayudi, M.A. (2017). Digestibility, growth, and pigmentation of astaxanthin, canthaxanthin, or lutein diets in Lake Kurumoi rainbowfish, Melanotaenia parva (Allen) cultured species. Aquac. Res., 48(11), 55175525.

Moses, M., Mtolera, M.S.P., Chauka, L.J., Lopes, F.A., de Koning, D.J., Houston, R.D., \& Palaiokostas, C. (2020). Characterizing the genetic structure of introduced nile tilapia Oreochromis niloticus strains in Tanzania using double digest RAD sequencing. Aquac. Int., 28(2), 477-492.

Novelo, N. \& Gomelsky, B. (2009). Comparison of two methods for measurement of red-area coverage in white-red fish for analysis of color variability and inheritance in ornamental koi carp Cyprinus carpio. Aquat. Living Resour., 22(1), 113-116.

Parichy, D.M., Elizondo, M.R., Mills, M.G., Gordon, T.N., \& Engeszer, R.E. (2009). Normal table of postembryonic zebrafish development: Staging by externally visible anatomy of the living fish. Dev. Dyn., 238, 2975-3015.

Pedersen, M. (2013). Angelfish: Genetic transparency changes everything. Amazonas, Freshwater Aquariums \& Tropical Discovery, p. 44-57.

Ponzoni, R., James, J., Nguyen, N., Mekkawy, W., Khaw Authors Ponzoni, H.R., \& Khaw, H. (2013). Strain comparisons in aquaculture species: A manual 2013-12. Penang, Malaysia: WorldFish.

Putra, H.I. (2014). How to become a successful ornamental fish entrepreneur. In: REIKKA 2014 Report. Depok, Indonesia: BRBIH-KKP.

Rankin, K.J., McLean, C.A., Kemp, D.J., \& Stuart-Fox, D. (2016). The genetic basis of discrete and quantitative colour variation in the polymorphic lizard, Ctenophorus decresii. BMC Evol. Biol., 16(1), 179.
Ríos-Villamizar, E.A., Piedade, M.T.F., Da Costa, J.G., Adeney, J.M., \& Junk, W.J. (2013). Chemistry of different Amazonian water types for river classification: A preliminary review. WIT Trans. Ecol. Environ., 178, 17-28.

Rodi Fish Farm. (2019). Sales data of tetra fish. Depok, Indonesia: Rodi Fish Farm. Unpublished data.

Rodrigues-Filho, J.L., Abe, D.S., Gatti-Junior, P., Medeiros, G.R., Degani, R.M., Blanco, F.P., ... \& Tundisi, J.G. (2015). Spatial patterns of water quality in Xingu River Basin (Amazonia) prior to the Belo Monte dam impoundment. Braz. J. Biol., 75(3), 34-46.

Sahoo, L., Mohanty, M., Meher, P.K., Murmu, K., Sundaray, J.K., \& Das, P. (2018). Population structure and genetic diversity of hatchery stocks as revealed by combined mtDNA fragment sequences in Indian major carp, Catla catla. Mitochondrial DNA Part A, p. 1-7.

Salis, P., Roux, N., Soulat, O., Lecchini, D., Laudet, V., \& Frédérich, B. (2018). Ontogenetic and phylogenetic simplification during white stripe evolution in clownfishes. BMC Biol., 16(1), 1-13.

SeriouslyFish. (2012). Paracheirodon innesi (Myers, 1936) neon tetra: Selectively bred 'diamond' strain. Retrieved June 12, 2019, from https://www. seriouslyfish.com/species/paracheirodon-innesi/.

Shaddock, P. (2012). Guppy color strains. Third Edition. Vancouver, Canada: Guppy Designer.

Weitzman, S.H. \& Fink, W.L. (1983). Relationships of the neon tetras, a group of South American freshwater fishes Teleostei, Characidae, with comments on the phylogeny of new world. Bull. Mus. Comp. Zool., 150(6), 339-395.

Zhang, Y., Liu, J., Fu, W., Xu, W., Zhang, H., Chen, S., ...\& \&iao, Y. (2017). Comparative transcriptome and DNA methylation analyses of the molecular mechanisms underlying skin color variations in Crucian carp Carassius carassius L. BMC Genet., 18(1), 95. 


\section{SUPPLEMENT}

RCC Variation in Sex and Sizes and RCC Position in The Body of Neon Tetra

Red color coverage (RCC) of cultured neon tetra is formed by red pigment cells (erythrophore) associated with other color cells. RCC is distributed from caudal fin to adipose fin in dorsal, go down to stomach area, anal fin in the abdomen area, and then back to caudal fin (Supplement 1b). Erythrophore overlapping melanophore on the back of the lateral area
(Supplement 1c), in the top, middle, and bottom of caudal peduncle area (Supplement 1d), in the dorsal and the end of the neon strip (Supplement 1e), and then enter the back of the stomach area and partially covered silver-gold of the structural color cell (leuco phore/iridophore) (Supplement 1f). Red pigment area is also found in the front edge of an adipose fin in the dorsal region (Supplement $1 \mathrm{~g}$ ) and dorsal fin rays (Supplement $1 \mathrm{~h}$ ). In our study, the RCC character was only the red pigment on the body, not including on the fins (Supplement 1a).

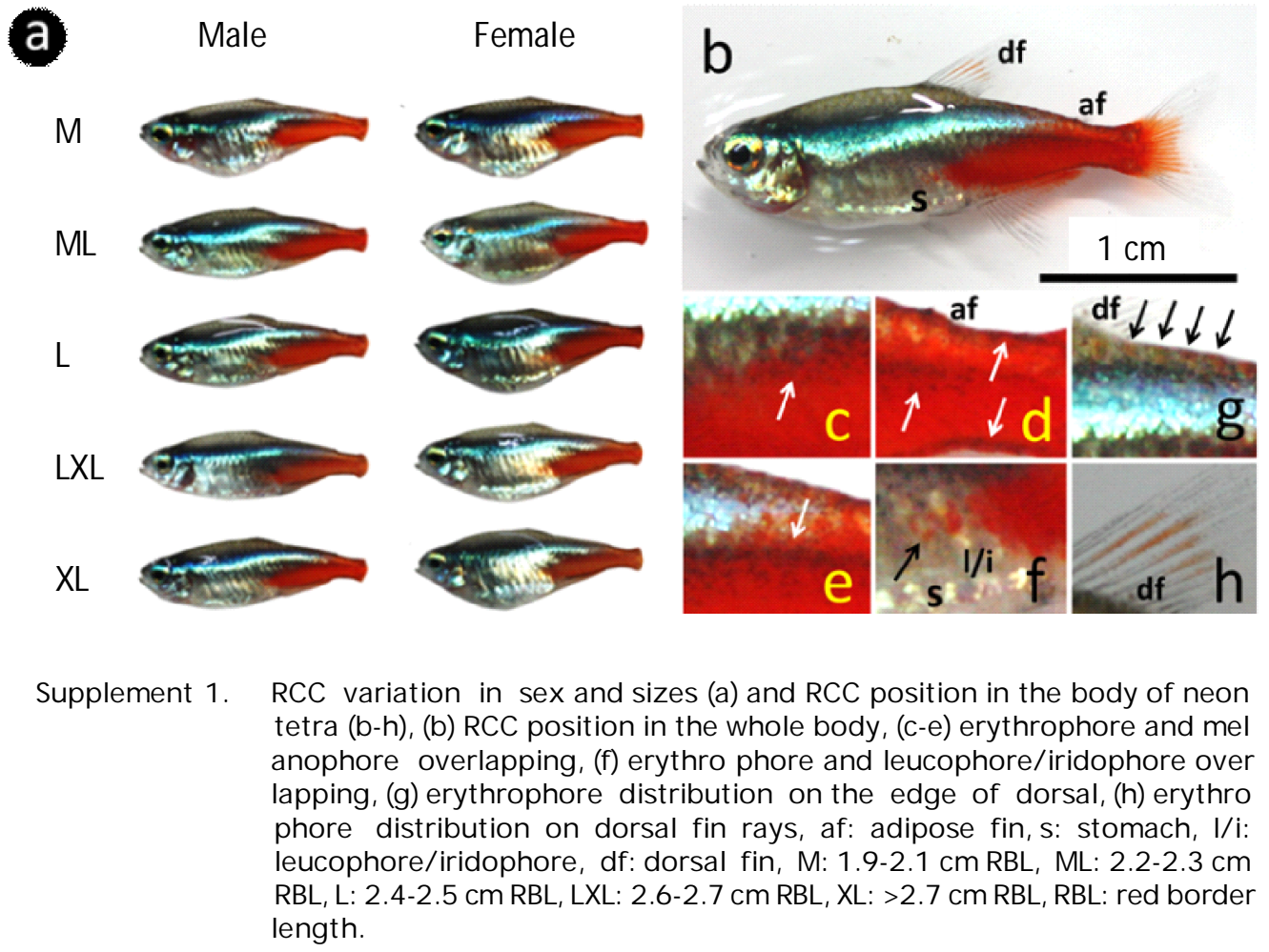

